\title{
ІМІДЖ МАЙБУТНЬОГО КЕРІВНИКА ЗАКЛАДУ ОСВІТИ У КОНТЕКСТІ ПРОФЕСІЙНОЇ ПІДГОТОВКИ
}

\author{
O. I. Мармаза \\ професор кафедри наукових основ управління \\ Харківського національного педагогічного університету імені Г. С. Сковороди
}

Суспільні трансформації, зміни у політичних, економічних та соціокультурних процесах, модернізація освіти висувають нові вимоги до якості підготовки майбутнього керівника закладу освіти, становлення його професіоналізму, формування іміджу та ділової репутації.

Реалізація визначених у Законі України «Про освіту» Національній стратегії розвитку освіти в Україні на період до 2021 року вимог до професіоналізму вимагають підготовки керівників, які можуть стратегічно мислити, створювати інтелектуальні цінності, організовувати ефективні комунікаційні процеси, творчо підходити до справ, гідно представляти свою організацію за ії межами, постійно дбати про підвищення власної компетентності та удосконалення майстерності.

Від професійної позиції керівника, його особистісних якостей, ціннісних орієнтацій залежить характер взаємовідносин у колективі, творча та ділова атмосфера у закладі. Імідж керівника стає наразі необхідним атрибутом соціально-професійних відносин, так як відображає значущі з позиції масової свідомості особливості особистості, професійної діяльності, спілкування, поведінки та зовнішнього образу керівника. Таким чином, існують об'єктивні потреби сучасного закладу освіти у особистості керівника, орієнтованого на професіоналізм, успішність, позитивний імідж.

Формування іміджу є процесом самопрезентації особистості. Уміння правильно представити себе, щоб бути авторитетним, презентабельним, конкурентноздатним, зумовлюють важливість вивчення іміджології. Іміджологія - це практична комплексна дисципліна, що використовує результати ряду наук (соціології, психології, менеджменту, культурології та ін.) з метою створення й перетворення іміджу певних суб'єктів та об'єктів.

Професійний імідж майбутніх керівників починає формуватися під час навчання студентів у закладах вищої освіти за спеціальністю 073 «Менеджмент», де закладаються основи фахової діяльності. Проте цілеспрямована робота саме з формування іміджу майбутнього керівника в умовах вузівської підготовки майже відсутня. Поодинокі згадування про імідж під час освітньої діяльності не створюють системного уявлення студентів про імідж керівника та засоби його формування.

На основі аналізу науково-методичної джерельної бази з означеної проблеми було з'ясовано сутність основних понять іміджування. Так, встановлено, слово «імідж» походить від лат. imago - «образ» і означає цілеспрямовано сформований образ (певної особи, явища, предмета), який підкреслює ціннісні характеристики та покликаний здійснювати емоційно-психологічний вплив на будь-кого. Найбільш поширеним $є$ визначення іміджу як образу, що склався у масовій свідомості і має характер стереотипу. Про імідж говорять як про образ візуальний та символічний.

У сучасному словнику Н. Вебстера наведено таке визначення: «Імідж - похідне від «свідомість», утворене за допомогою мови зображення або опис; розумова концепція, підтримувана різними суспільними групами і така, що символізує основну позицію й орієнтацію у відношенні до чого-небудь (особи, класу, расового типу, політичної філософії або національності)» [6, с. 483].

У соціологічних і психологічних дослідженнях імідж розглядається як загальне враження, а призначення іміджу - в забезпеченні досягнення ефекту привабливості та комфортності спілкування. Управлінський аспект проблеми іміджу відображено у працях Б. Андрюшкіна, О. Ільїна, А. Панасюка, Ф. Хміля, В. Шепеля, В. Яцури. Діяльність керівника щодо створення іміджу організації та персоналу розкрито в дослідженнях О. Доброневського, О. Омарова, Г. Почепцова, О. Перелигіна, Е. Уткіна. Важливість формування іміджу педагога та керівника освіти висвітлено у роботах О. Горовенко, Л. Даниленко, 3. Тимошенко, О. Казачінер, А. Калюжного, Ю. Палєхи та ін.

Встановлено, що імідж керівника - це цілісний несуперечливий образ, що виникає у свідомості оточуючих, який відповідає цілям, нормам, цінностям, прийнятим у певній групі (персонал, учні, батьки, керівники вищої ланки, громадськість тощо). Імідж - це те, як люди сприймають керівника; оцінюють його, співвідносячи із власною (груповою, суспільною) системою цінностей; як ставляться до нього у результаті сприйняття внутрішніх та зовнішніх характеристик. Отже, особистісно-професійний імідж керівника - це образ, що формується у процесі професійної діяльності та забезпечує самореалізацію особистості.

Імідж - це тільки той образ, до якого у інших людей є ставлення, думка про нього. Тому керівник повинен розвивати уміння оцінювати себе з боку педагогів, учнів, батьків та інших суб'єктів професійної взаємодії; встановити свою значущість; об' єктивно оцінювати свої особистісні якості. Це є підгрунтям для визначення свого реального та бажаного іміджу. Імідж повинен бути усвідомленим для того, щоб його змінювати, удосконалювати. 
Визначають ціннісні та технологічні функції іміджу. До ціннісних функцій іміджу належать: особистісного піднесення (завдяки позитивному іміджу підкреслюється духовність, гідність, індивідуальна непересічність); психотерапевтична (приваблива особистість отримує визнання, увагу, повагу, що забезпечують їй оптимізм, мажорний настрій, впевненість у собі). Технологічні функції іміджу — це: соціальної адаптації (завдяки позивному іміджу можливе більш швидке та безпроблемне входження у певне середовище); висвітлення кращих особистісних та ділових якостей (зосередження уваги оточуючих на перевагах); затінення негативних якостей (відвернення уваги оточуючих від зовнішніх даних, манер та інших недоліків); концентрація уваги на собі (зосередження уваги на своїх словах, діях сприяє приверненню інтересу до особистості); розширення вікового діапазону спілкування (засвідчує належність до сучасних тенденцій манер і комунікацій, дозволяє розширяти ділові контакти в різновікових соціумах).

Діяльність керівника, будучи публічною, висуває особливі вимоги до такого професійного уміння, як самопрезентація, яка виступає своєрідним механізмом іміджування, тобто конструювання свого образу для інших.

Процес формування особистісно-професійного іміджу складається із декількох послідовних кроків: 3'ясувати вимоги аудиторії, на яку розрахований імідж; проаналізувати свої сильні та слабкі сторони; сконструювати майбутній образ; перевести образ у вербальну, візуальну та діяльнісну сфери [2].

Безумовна потреба у дослідженні проблеми формування іміджу майбутнього керівника засобами самопрезентації полягає у тому, що існує об'єктивна необхідність навчання самопрезентації в умовах професійної вузівської підготовки, а науково-методичних матеріалів 3 даного аспекту замало.

Термін «самопрезентація» (self-presentation), був вперше використаний И. Гофманом. На його думку, самопрезентація - це засіб організації власної поведінки людиною [1]. В. Шепель визначає самопрезентацію як уміння подати себе, привертаючи до себе увагу, актуалізуючи інтерес людей до якихось своїх якостей. Автор наголошує на тому, що у самопрезентації недостатньо спиратися на власні обдарування і знання. Необхідна спеціальна підготовка, і перш за все - уміння орієнтуватися в основних складових цього процесу [5].

3 явищем самопрезентації ми зіштовхуємось щодня, часто, навіть не підозрюючи, що у своїй підсвідомості у нас сформований проект власної презентації. Такого роду презентацію прийнято називати природною самопрезентацією. Вона властива усім людям без виключення і отримується з народження. Головним недоліком природної самопрезентації є те, що людина свідомо не контролює і не аналізує процес формування іміджу. Існує і заздалегідь спланована, усвідомлена тактика позиціювання своєї особистості, яку прийнято називати штучною презентацією, головна мета якої полягає у прихиленні до себе значимої групи людей.

Отже, сутність самопрезентації полягає в тому, щоб за допомогою ефективних методів і засобів уплинути на аудиторію, донести до оточуючих важливу й необхідну інформацію, аргументовано викласти свою позицію, думку, точку зору.

У наукові джерельній базі з іміджування(А. Калюжний, Ю. Палєха, Г. Почепцов) розкрито різні стратегії формування іміджу, зокрема:

- Позиціонування - це представлення себе у сприятливому образі. Допомагає створити сприятливе інформаційне середовище, виграти на фоні інших. Робить можливим обмежитись лише потрібними якостями чи характеристиками, що потрібні аудиторії, приховати непотрібні властивості чи недоліки.

- Маніпулювання. Передбачає уміння переносити увагу з однієї інформації (якості, характеристику) на іншу, керувати сприйняттям. Маніпулювання пов'язане із вигадками, легендами та міфами, що відволікають увагу від основного.

- Міфологізація передбачає поширення такої інформації, щоб імідж підкріплювався новими фактами, атрибутами, які б підсилювали створюваний образ.

- Емоціоналізація. За Г. Почепцовим, це переклад з раціональної мови на емоційну [4]. Додати ще епітети, емоційно забарвлені слова, співпереживання. Передбачає підстроювання під чужі емоції, настрої, бажання (ми вам співчуваємо, ми з вами, ми вам допоможемо, ми раді за вас і т. д.).

- Деталізація передбачає уміле оперування деталями, дрібничками, які у вигідному ракурсі представляють об'єкт (керівник грає на гітарі, танцює, малює, у минулому був спортсменом тощо).

- Метафоризація передбачає використання різного роду тропів, слів у переносному значенні, які дозволять підсилити, або зруйнувати імідж («Ганна Іванівна — наша зірка», «це — не колектив, а болото» й таке інше).

- Вербалізація - уміле використання слова, ораторське мистецтво, красномовство. За допомогою мови можна змінити враження, орієнтацію, оцінку. Для цього також використовується перекручування інформації, свідоме опущення певних елементів, надання надмірного значення іншим.

- Візуалізація це представлення об'єкту на фото, слайдах, у кліпах, кінороликах. Допомагає аудиторії краще запам'ятати, за допомогою кращих ракурсів зображення показати у вигідних ситуаціях (демонстрація фото, де керівник разом із відомою людиною, мером, депутатом тощо).

- Дистанціювання передбачає перекладання на інших відповідальності, самоусунення від подій («адміністрація відділу освіти наказала зробити...»).

- Впровадження моделей сприйняття. Це зумовлює отримання прогнозованого, очікуваного результату (манери, мова, ставлення, одяг). 
3-поміж різних інструментальних засобів формування іміджу керівник повинен обрати ті, які б були не одноразовими, не популістськими, а реально сприяли становленню стійкого позитивного іміджу. Основними критеріями повинні бути: відповідність чинному законодавству, моральна бездоганність, врахування ситуації комунікацій, цілеспрямованість.

Усе зазначене вище дозволяє зробити висновок, що особливості вибору засобів самопрезентації є виявом ідентичності особистості. Не викликає сумнівів, що керівник повинен опанувати різні технології самопрезентації, тобто навчитись управляти враженням про себе.

Базова модель технології побудови іміджу складається з таких позицій самопрезентації: «Я-концепція» морально-психологічна підготовка; фейсбілдінг - створення зовнішності особистості з урахуванням усіх супутніх чинників; кінесика - тілесне інформування; дизайн одягу — підбір і носіння одягу, використання аксесуарів; володіння словом - риторична оснащеність; флюїдне випромінювання — створення особистісного «біоенергетичного поля»; комунікативна механіка - майстерність спілкування.

Самопрезентація співвідноситься із саморозкриттям. Проте саморозкриття передбачає обмеженість тільки інформацією про себе, а самопрезентація - це ще й продумана подача цієї інформації. Ефект враження глибоко фіксується у свідомості оточуючих і надовго визначає характер стосунків, змінити який надалі виявляється нелегко.

Не менш важливе значення для успішної самопрезентації відіграє самооцінка та самоповага. У процесі самопрезентації, як правило, виникає бажання показати себе з кращого боку, щоб бути позитивно сприйнятим оточуючими.

Водночас результати наших пілотних досліджень, проведених серед студентів зі спеціальності «Менеджмент» (освітня програма «Управління навчальним закладом»), засвідчують, що студентська громада мало усвідомлює значення самопрезентації, має недосконалу уяву про різні форми самопрезентації, а це означає, що процес формування іміджу відбувається спонтанно. Так, серед мотивів, що спонукають майбутніх керівників до розвитку особистісно-професійного іміджу, лише $12 \%$ респондентів назвали самовдосконалення, $17 \%$ - розвиток професіоналізму. Більшість опитуваних до мотивів формування іміджу віднесли можливість заявити про себе (68 \%), досягнення визнання та поваги (82 \%). Це означає, що майбутні керівники більше уваги приділяють зовнішнім аспектам іміджу.

Таким чином, доцільніше в умовах вишу надавати студентам педагогічну підтримку в створенні позитивного особистісно-професійного іміджу засобами самопрезентації, вчити долати комунікативні бар'єри, адаптувати до нових соціальних умов через здобуття нових знань про самопрезентацію, орієнтування у ситуаціях спілкування, уявленні і захисті своїх інтересів.

Формування позитивної самопрезентації майбутнього керівника у процесі вузівської підготовки, на нашу думку, пов'язано з дотриманням деяких принципів особистісно орієнтованої технології освіти. Відтак, у освітньому процесі слід спрямувати роботу з підготовки майбутнього керівника до професійної діяльності за такими напрямами: орієнтація на визнання позитивних якостей, сильних сторін, значущості особистості; уміння мотивувати інших до діяльності і досягнення в ній позитивних результатів; розвиток конкретних комунікативних вмінь; володіння культурою мовлення; виховання поваги до самого себе, знання власних сильних сторін, уміння використовувати їх у власній діяльності; тренування у контролюванні свого емоційного стану; прищеплення установки студентів щодо цілеспрямованого формування іміджу.

Зазначимо, що для формування іміджу майбутнього керівника важливим у освітньому процесі $є$ використання форм активного навчання. Ділові ігри створюють можливість для імітації моделі поведінки майбутнього керівника, розвитку свідомості, формування способів професійної діяльності, рефлексії. У такий спосіб можна упередити неефективну діяльність та неефективну поведінку керівника у майбутньому, що у реальному професійному житті негативно вплинули б на його імідж.

Формування особистісно-професійного іміджу майбутнього керівника засобами самопрезентації відбувається через залучення студентів до творчо-пошукової діяльності. Це, передусім, індивідуальні завдання творчого характеру, які передбачають проведення досліджень з різних проблем управління закладом освіти, дозволяють виявити стан готовності студента до керівної діяльності.

Добровільність участі студентів у різноманітних семінарах, тренінгах, творчих лабораторіях, конференціях — це перші ознаки роботи над власним іміджем. У цьому їм треба допомогти засобами створення індивідуальних моделей самопрезентації та розкриття технік самопрезентації.

Особливістю навчання студентів у магістратурі зі спеціальності 073 «Менеджмент» (освітня програма «Управління навчальним закладом») є те, що в групах одночасно присутні керівники з досвідом роботи, новопризначені та ті педагоги, що входять до керівного резерву. Це сприяє кращому засвоєнню прийомів іміджування. Спілкування, обмін думками, спостереження стають неоціненним надбанням для формування особистісно-професійного іміджу поряд із здобутими знаннями.

Результатом такого підходу до формування особистісно-професійного іміджу майбутнього керівника під час навчання в магістратурі може стати розробляння індивідуальних проектів з формування позитивного іміджу.

Проект з формування іміджу повинен містити науково-практичні семінари і тренінги, конференції та ділові ігри, спецкурси з проблем іміджології та індивідуальні консультації психолога, стиліста, косметолога, лікаря. 
Актуалізації професійного іміджу майбутнього керівника будуть сприяти його участь у всіх сферах життєдіяльності базового закладу освіти, у якому він проходить виробничу та науково-дослідну практики, виконує наукове дослідження для випускної роботи. Особливу увагу слід приділити заходам, які створюють умови для самопрезентації: конференції, конкурси, диспути, фестивалі педагогічних ідей, декади передового досвіду тощо.

Такі заходи повинні допомогти майбутньому керівнику розкрити особистісні характеристики; моделювати індивідуальний стиль поведінки у різних життєвих ситуаціях; засвоїти цінності професії, правила управлінської поведінки; визначити засоби самоудосконалення; адаптуватись до соціокультурного простору закладу освіти; засвоїти технології та техніки формування та захисту іміджу; підвищити рівень саморегуляції; навчити засобам формування сприятливого іміджового середовища навколо себе; напрацювати стійкі навички конструктивної взаємодії; індивідуально дібрати засоби самовираження, які дозволяють більш повно розкрити свій потенціал; сформувати іміджеву компетентність.

Іміджева компетентність особистості складається із знань та розуміння сутності іміджоформуючих процесів, володіння універсальними базовими технологіями, техніками, засобами, навичками досягнення внутрішнього стану та зовнішньої виразності. Це здатність творчо діяти; створювати залежно від середовища, його динаміки та власних потреб свідомі образи, моделі себе та майбутніх результатів діяльності. Самоповага та впевненість у собі слугують підгрунтям іміджевої компетентності. Фактор креативності є важливою властивістю особистості для створення іміджу; це здатність до конструктивного та нестандартного мислення і поведінки, усвідомлення та розвитку свого досвіду. Соціально-психологічний іміджевий потенціал особистості передбачає наявність необхідного рівня здібностей та засобів їх об'єктивізації.

Таким чином, допомога майбутньому керівнику закладу освіти ще в умовах вузівської підготовки у вивченні іміджологічного простору, спрямуванні іміджоформуючої діяльності, виборі ефективних засобів самопрезентації дозволять у перспективі досягти свого акме у якості особистості та професіонала.

Подальші теоретико-прикладні дослідження повинні поглибити вивчення залежності іміджу керівника від суб'єктів комунікацій та сприйняття; розкрити механізми взаємозв'язку іміджу керівника та репутації закладу освіти; виявити ефективні засоби формування позитивного іміджу майбутнього керівника під час його навчання у закладі вищої освіти.

\section{Література}

1. Гофман И. Представление себя другим в повседневной жизни / пер с англ. А. Д. Ковалева. Москва : Канон-пресс-Ц : Кучково-поле, 2000. 302 c.

2. Мармаза О. І. Інноваційний менеджмент. Харків : Планета-принт, 2016. 197 с.

3. Палєха Ю. І. Іміджіологія : навч. посіб. / за заг. ред. 3. І. Тимошенко. Київ : Вид-во Свроп. ун-ту, 2005. 324 с.

4. Почепцов Г. Г. Профессия : имиджмейкер. Киев : ИМСО МО Украины, НВФ «Студцентр», 1998. 256 с.

5. Шепель В. Имиджология : секреты личного обаяния. Москва : Маркетинг, 1997. 382 с.

6. The Webster's Dictionary and Thesaurus of the English language. Lexicon Publications Inc., Dunbury, CT, USA, 1993. $1216 \mathrm{p}$. 